\title{
UPAYA SENAM DIABETES UNTUK PENDERITA DM TIPE II DI PUSKESMAS PONDOK RANGGON I JAKARTA TIMUR
}

\author{
Nayla Kamilia Fithri \\ Program Studi Kesehatan Masyarakat, Fakultas Ilmu Kesehatan, UPN Veteran Jakarta \\ Jl. RS. Fatmawati Raya, Pondok Labu, Jakarta \\ naylakamiliafithri@upnvj.ac.id
}

\begin{abstract}
Diabetes Militus increases the disease does not change depending on continuously from year to year. One area with a high incidence of hypertension and diabetes is the resident of Kohod Village. Where in the administration only drugs were given by the public health center. For this reason, we plan to provide programs in the form of hypertension and diabetes exercise activities, these activities can stabilize blood sugar and blood pressure for DM and hypertension sufferers. We know that administering drugs for the management of hypertension and diabetes has side effects that will be there, while regular exercise will not cause any side effects. For this reason, we invite partner 1, namely integrated healthcare center cadres and partner 2, namely people with hypertension and diabetes mellitus sufferers to carry out a program called healthy exercise. Where the problem occurs is a posyandu formed by cadres which can be useful for improving the quality of health, especially for people with hypertension and diabetes. Because these 2 problems are urgent problems that must be taken care of in Kohod Village, Tangerang. Activities carried out include presenting education and exercise training to posyandu cadres, and applying exercise programs to people suffering from diabetes mellitus. In the implementation of gymnastics, health checks will be carried out before and after exercise to see changes in blood sugar and blood pressure levels. Apart from providing training for cadres, the community was also given counseling on how to maintain health in order to keep blood pressure and blood sugar stable. The target of this service is to improve the qualifications of cadres in public health surveillance with training and in managing an activity so that it runs continuously, and also to improve the quality of life of people with diabetes mellitus and hypertension with stable blood pressure and blood sugar. In addition, it provides increased knowledge for partners in maintaining health and dealing with existing problems. The output of this program will be published in national journals and international proceedings and the mass media.
\end{abstract}

Keywords: DM, gymnastic, elderly people

\begin{abstract}
Abstrak
Diabetes Militus merupakan penyakit tidak menular yang jumlahnya terus meningkat dari tahun ketahun. Salah satu kawasan dengan kejadian hipertensi dan diabetes yang tinggi adalah penduduk Pondok Ranggon Jakarta Timur. Dimana dalam penatalsanaannya hanya diberikan obat oleh pihak puskesmas. Untuk itu kami berencana untuk memberikan usulan program berupa kegiatan senam hipertensi dan diabetes, kegiatan ini dapat menstabilkan gula darah dan tekanan darah bagi penderiat DM dan hipertensi. Kita ketahui bahwa pemberian obat untuk penatalaksanaan hipertensi dan diabetes mempunyai efek samping yang akan dihadapi, sedangkan senam yang dilakukan secara rutin tidak akan menimbulkan efek samping apapun. Untuk itu kami, mengajak mitra 1 yaitu para kader posyandu dan mitra 2 yaitu penderita hipertensi dan penderita diabetes militus untuk melakukan suatu program yang dinamakan senam sehat. Dimana permasalahan yang terjadi adalah posyandu yang dibentuk oleh para kader dapat bermanfaat untuk meningkatkan kualitas kesehatan, terutama bagi para penderita hipertensi dan diabetes. Karena 2 masalah tersebut merupakan masalah urgent yang harus ditangani yang ada Di Pondok Ranggon Jakarta Timur, Tangerang. Kegiatan yang dilakukan adalah pemberian edukasi dan pelatihan senam kepada para kader posyandu, dan mengaplikasikan program senam kepada masyarakat yang menderita diabetes militus. Dalam pelaksanaan senam, akan dilakukan pemeriksaan kesehatan sebelum dan sesudah senam untuk melihat perubahan kadar gula darah dan tekanan darah. Selain pemberian pelatihan bagi kader, masyarakat juga diberikan penyuluhan bagaimana menjaga kesehatan agar tetap stabil tekanan darah dan gula darahnya. Target dari pengabdian ini adalah meningkatkan kualifikasi para kader dalam menjaga kesehatan masyarakat dengan adanya pelatihan dan dalam memanajemen suatu kegiatan agar berjalan secara kontinue, dan juga meningkatkan kualitas hidup dari penderita diabetes militus dan hipertensi dengan stabilnya tekanan darah dan gula darah. Selain itu dapat memberikan peningkatan pengetahuan bagi mitra dalam menjaga kesehatan dan menghadapi permasalahan yang ada.Luaran hasil program ini akan dipublikasikan pada jurnal nasional dan prosiding internasional dan media masa.
\end{abstract}

Kata kunci: diabetes militus, senam, lansia 


\section{Pendahuluan}

International Diabetes Federation atau IDF mengemukakan bahwa tahun 2015, sekitar 415 juta orang di dunia diperkirakan menderita DM. Sedangkan pada tahun 2017, penderita DM semakin meningkat menjadi 425 juta diseluruh dunia. Jumlah terbesar orang dengan DM yaitu berada di wilayah Pasifik Barat 159 juta dan Asia Tenggara 82 juta. China menjadi negara dengan penderita DM terbanyak di dunia dengan 114 juta penderita, di ikuti dengan India 72,9 juta, lalu Amerika serikat 30,1 juta, kemudian Brazil 12,5 juta dan Mexico 12 juta penderita. Indonesia menduduki peringkat ke-6 untuk penderita DM dengan jumlah 10,3 juta penderita(International Diabetes Federation, 2017). Diabetes Militus (DM) merupakan penyakit gangguan kronik pada metabolisme yang ditandai dengan hiperglikemia yang berhubungan dengan abnormalitas metabolisme karbohidrat, lemak dan protein yang sidebabkan oleh defisiensi insulin relatif atau absolut(International Diabetes Federation, 2015). Sedangkan penyakit hipertensi didefinisakan berdasarkan ambang batas untuk tekanan darah sistolik dan diastolik yang diukur dalam mmHg. Tekanan darah dikatakan tinggi jika dalam keadaan istirahat tekanan diastolik terusmenerus diatas $90 \mathrm{mmHg}$ dan atau nilai tekanan darah sistolik $140 \mathrm{mmHg}$ atau lebih setelah pengulangan pengukuran (Inzucchi, 2003).

Penyakit hipertensi dan DM akhir-akhir ini tidak hanya menyerang negara-negara maju saja, tetapi juga dialami oleh penduduk dinegara-negara berkembang, salah satu contohnya adalah Di Indonesia. Menurut International Diabetes Federation (IDF) Tahun 2002, Indonesia menempati urutan ke-4 dengan jumlah penderita DM terbesar di dunia setelah India, Cina dan Amerika Serikat. Hasil studi Survei Kesehatan Rumah Tangga (SKRT) Tahun 1992, 1995, dan 2001 menyebutkan bahwa hipertensi selalu berada pada peringkat pertama dari 10 besar penyakit terbanyak yang diderita oleh penduduk Di Indonesia dengan prevalensi yang terus meningkat dan menyebabkan kematian (Soemantri and Sarimawar, 2002). Banyak faktor yang dapat menyebabkan 2 permasalahan tersebut diantaranya bisa dari gaya hidup seperti kurang aktifitas fisik dan merokok, atau pola makan yang salah serta obesitas yang dialami.

Data diatas menunjukkan bahwa penduduk usia lanjut sangat tinggi. Selain permasalahan kemiskinan, permasalahan kesehatan yang dialami oleh masyarakat Pondok Ranggon Jakarta Timur cukup serius dan urgent, berdasarkan wawancara dengan pimpinan posyandu yaitu disebutkan bahwa penyakit hipertensi dan diabetes militus selalu mendudduki peringkat tertinggi dari 10 besar penyakit yang dialami oleh masyarakat Pondok
Ranggon Jakarta Timur. Masalah ini menjadi serius ketika penyakit hipertensi juga dialami oleh ibu hamil dan menyebabkan kematian, Selain dialami oleh Lansia yang jumlahnya sangat banyak di desa tersebut. Untuk itu kami tim pengusul bekerjasama dengan para kader untuk melakukan pengendalian dan peningkatan kualitas hidup bagi para penderita hipertensi dan diabetes militus dengan penata laksanaan non farmakologis yang berupa senam. Dimana kegiatan ini belum dilaksanakan dan belum masuk di program posyandu. Kegiatan ini diharapkan dapat mengatasi 2 permasalahan kesehatan yang sedang dialami oleh masyarakat di Kampung Alar Pondok Ranggon Jakarta Timur Tangerang. Berdasarkan uraian diatas, maka dipandang perlu untuk melakukan intervensi senam hipertensi pada penderita hipertensi di Puskesmas Kelurahan Pondok Ranggon I yang dilaksanakan pada kegiatan pengabdian masyarakat ini. Tujuan dari pengabdian masyarakat ini adalah tersedianya informasi mengenai pengetahuan penyakit Diabetes Militus dan senam DM untuk proses yang berkesinambungan dalam menurunkan angka kejadian penyakit DM Tipe II.

\section{Metode Pelaksanaan}

Metode yang dilakukan dalam pengabdian ini adalah memberikan pelatihan senam hipertensi dan senam diabetes. Dalam Pelaksanaan pengabdian ini mempunyai 3 sasaran yaitu penderita hipertensi, penderita diabetes militus dan kader posyandu. Program pengabdian yang diadakan adalah dengan mengadakan senam secara langsung kepada masyarakat penderita diabetes militus dan hipertensi yang rutin dilakukan selama 1 minggu $3 x$ dalam durasi selama 4 bulan pertama. Dalam pelaksanaanya akan dilakukan pemeriksaan tekanan darah dan gula darah sebelum dan sesudah pelaksanaan senam. Selain itu juga dilaksanakan Penyuluhan sebelum dilakukan senam terkait dengan penyakit hipertensi dan diabetes yang diderita, dan konsultasi dengan bekerjasama dengan dokter setempat. Selain itu dilakukan pelatihan kepada 10 Kader Posyandu berupa gerakan senam hipertensi. Tujuannya adalah agar bisa dilaksanakan senam mandiri dengan dipimpin sendiri oleh para kader yang tinggal Di Pondok Ranggon Jakarta Timur Kampung Alar tersebut. Sehingga senam ini bisa dilaksanakan secara kontinyu dan konsisten. Kemudian dilakukan monitoring dan pendampingan selama 4 bulan setelah pelatihan kader, untuk mengevaluasi kegiatan senam tersebut apakah berjalan atau tidak.

Senam dimulai pada pukul 07:45 WIB. Kegiatan ini dilakukan selama 30 menit. Senam dilakukan selama 5 kali dalam 1 minggu. Gerakan senam terdiri dari pemanasan (5-10 menit), inti (2030 menit) dan pendinginan (5-10menit). Senam 
dilaksanakan di lapangan depan Puskesmas Kelurahan Pondok Ranggon 1 dan dipimpin oleh instruktur senam yang sudah mengikuti pelatihan atau bersertifikasi. Prinsip gerakan senam diabetes harus sesuai dengan CRIPE (Continious, Rhytmical, Interval, Progressive, Endurance)(Santoso, 2008). Peregangan

a. Gerakan 1

Kaki dibuka selebar bahu. Kedua tangan dirangkai di atas kepala. Badan dankepala dicondongkan ke kanan. Pandangan ke depan. Tahan hingga delapanhitungan. Kembali ke tengah, ulangi untuk sisi sebaliknya.Gerakan 2Kaki dibuka selebar bahu. Tangan mengepal di samping badan, bahu diangkat dandiputar. Pada setiap hitungan, posisi bahu diangkat. Lakukan 4 x 8 hitungan.

b. Gerakan 2

Kaki dibuka selebar bahu. Tangan mengepal di samping badan, bahu diangkat dandiputar. Pada setiap hitungan, posisi bahu diangkat. Lakukan 4 x 8 hitungan.

Pemanasan

a. Gerakan 1

Kaki dibuka selebar bahu. Lutut ditekuk dan digerakkan turun naik. Tangan didepan dada, telapak tangan dikibas-kibaskan. Lakukan 2 x 8 hitungan, bergantiandalam posisi serong kiri, ke depan, dan serong kanan.

b. Gerakan 2

Kaki dibuka selebar bahu. Lutut ditekuk, gerakkan turun naik. Siku diangkatsetinggi dada dengan gerakan telapak tangan seolah memutar bola. Lakukan 2 x 8hitungan bergantian dalam posisi serong kanan, ke depan, serong kiri

Inti

a. Gerakan 1

Angkat lutut kanan sejajar paha. Kaki kiri lurus. Kedua siku diayun di depan dada(tangan kanan di atas). Ganti angkat lutut kiri, kaki kanan lurus. Dua siku diayun didepan dada (tangan kiri di atas). Lakukan bergantian dengan hitungan 1 x 8 .

b. Gerakan 2

Buka kaki selebar bahu. Langkahkan kaki bergantian ke samping kiri dan kanansatu langkah. Tangan didorong ke atas dan ke bawah dengan mengepal. Lakukandengan hitungan 1 x 8 .

Pendinginan

a. Gerakan 1
Kaki dibuka selebar bahu, badan tegak menghadap ke depan. Tangan kanan memegang bahu kiri, tangan kiri memeluk pinggang kanan. Tekuk kaki kanan duahitungan, kaki kiri lurus; lalu ganti tekuk kaki kanan dua hitungangan, kaki kirilurus. Lakukan bergantian dalam 1 x 8 .

b. Gerakan 2

Buka kaki selebar bahu, badan tegak menghadap ke depan, tangan direntangkan. Tekuk kaki kanan dua hitungan, kaki kiri lurus; lalu ganti tekuk kaki kiri duahitungan, kaki kanan lurus. Lakukan bergantian dalam 1 x 8 hitungan

Alat yang digunakan untuk mendukung kegiatan senam ini berlangsung yaitu kaset senam dan tape player yang disediakan oleh peneliti. Ditengah-ditengah senam berlangsung, peneliti boleh memberikan air mineral kepada peserta DM untuk menghindari adanya kelelahan pada responden. Agar hasil yang didapatkan bisa akurat bahwa senam diabetes mampu menurunkan kadar gula darah pada pasien DM.

\section{Hasil dan Pembahasan}

Pengabdian masyarakat dilaksanakan tanggal 22 maret 2018 dengan total peserta 41 orang.Kegiatan pengabdian masyarakat dimulai dengan pembukaan sambutan dari kepala puskesmas dan ketua pelaksana, setelah itu dilanjutkan dengan kegiatan senam DM selama kurang lebih 30 menit. Pada pukul 7.30. Penatalaksanaan DM terdiri atas 4 pilar yang terdiri dari edukasi, terapi gizi medis, diet nutrisi dan latihan jasmani. Tujuan pokok pelaksanaan terapi gizi medis antara lain mempertahankan kadar glukosa darah mendekati normal (gdp 90-130 $\mathrm{mg} / \mathrm{dl})$, gdpp (<180 mg/dl), tekanan darah $<130 / 80$ $\mathrm{mg} / \mathrm{dl}$, mmeperbaiki sistem koagulasi darah, berat badan memadai, menghindari dan menangani komplikasi akut orang yang diabetes(Ernawati, 2017).

Prinsip senam diabetes sama dengan latihan jasmani secara umum yaitu memenuhi frekuensi, intensitas, durasi dan jenis. Senam Diabetes Militus menganjurkan latihan-latihan aerobik (olahraga ketahanan) yang teratur serta cukup takarannya untuk mencegah risiko DM Tipe II. Untuk mencapai hasil optimal, latihan dilakukan secara teratur 3$5 \mathrm{x} /$ minggu, sedikitnya $3 \mathrm{x} /$ minggu dengan tidak lebih dari 2 hari berurutan tanpa latihan jasmani karena peningkatan sensitivitas insulin tidak lebih dari 72 jam(Szmuilowicz, Josefson and Metzger, 2019). Manfaat Senam Diabetes Latihan jasmani/senam diabetes secara umum bermanfaat bagi penatalaksanaan diabetes Melitus yaitu: 
1. Membakar kalori dan mengurangi lemak tubuh sehingga meningkatkan kemampuan metabolisme sel dalam menyerap dan menyimpan glukosa.

2. Meningkatkan sirkulasi darah, terutama pada kaki dan tangan, dimana biasanya penderita diabetes memilki masalah

3. Mengurangi stress yang sering menjadi pemicu kenaikan glukosa darah

4. Penderita diabtes yang rajin berolah raga dapat melepaskan diri dari ketergantungan pada obat.

Menurut penelitian Hermawan dan Rosid Tahun 2010 pada penderita DM tipe 2, latihan jasmani memiliki peran utama dalam pengaturan kadar glukosa darah. Pada saat berolaharaga, keadaan permabilitas membran terhadap glukosa meningkat pada otot yang berkontraksi sehingga resisitensi insulin berkurang, dengan kata lain sesitivitas insulin meningkat(Hermawan and Rosid, 2017).

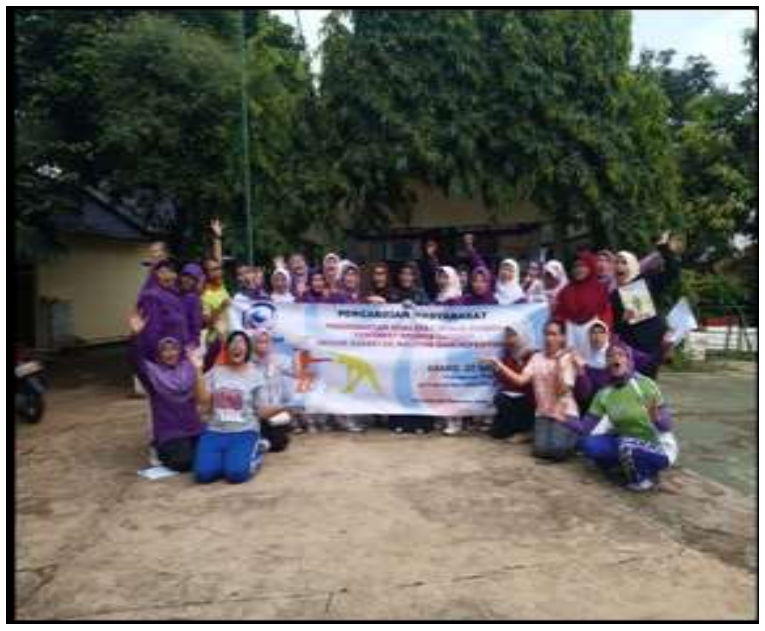

Gambar 1.

Kegiatan Senam dan Edukasi

Kegiatan dilanjutkan dengan kegiatan sosialisasi / edukasi mengenai penyakit hipertensi. Materi tekait dengan sosialisasi ini terdiri dari pengertian hipertensi, dampak penyakit hipertensi, penyebab dan pencegahannya. Pada pelaksanaan sosialisasi terlihat bahwa peserta sangat antusias dalam mengikuti kegiatan sosialisasi tersebut.

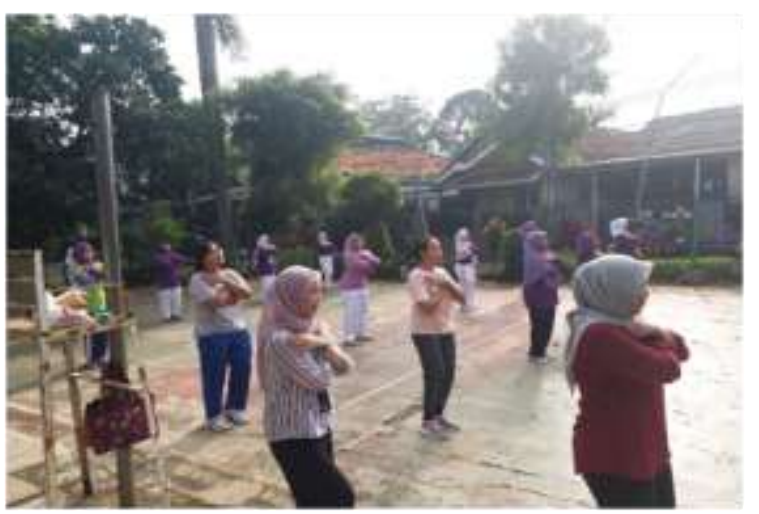

Gambar 2.

Senam Bersama Masyarakat

Pada waktu berolahraga dalam waktu singkat, ambilan glukosa oleh otot yang sedang aktif bergerak meningkat 7-20 kali lipat, tergantung pada intensitas gerak yang dilakukan. Glikogen hati digunakan untuk memnuhi kebutuhan glukosa oleh karena itu kadar glukosa darah tetap dalam keseimbangan atau menurun hanya sedikit sekali. Apabila olaharaga berlangsung 90 menit atau lebih, asam lemak merupakan sumber tenaga yang diperlukan. Apabila asam lemak otot meningkat dengan nyata, dan dalam waktu yang bersamaan, pembakaran glukosa menurun menjadi $20-40 \%$ dari sebelumnya. Perubahan ini mencegah penurunan kadar glukosa darah yang terlalu cepat. Setelah beberapa jam berolahraga sumber glukosa darah sekarang berasal dari gluconeogenesis (A, Mulyadi and J, 2016).

Kegiatan pengabdian masyarakat ini sangat banyak mendapat dukungan dari berbagai pihak, terutama daripihak puskesmas yang telah menjadi mitra kerjasama dalam kegiatan ini. Selain itu juga kegiatan pengabdian masyarakat ini dibantu oleh beberapa mahasiswa kesehatan masyarakat. Masyarakat sangat antusias dalam mengikuti kegiatan pengabdian masyarakat ini sampai selesai. Hal ini dapat terlihat dari semangatnya masyarakat dalam mengikuti senam dan banyaknya masyarakat yang mengajukan pertanyaan saat dilakukan sosialisasi.

\section{Kesimpulan}

Kegiatan pengabdian masyarakat ini memberikan peningkatan pengetahuan mengenai penyakit DM dan cara penanganan DM dengan senam. Kegiatan pengabdian masyarakat ini dapat berjalan dengan lancer dan kondusif. Masyarakat juga sangat antusias dalam mengikuti kegiatan ini sampai selesai. Sebaiknya kegiatan senam DM dilaksanakan secara terus menerus dan dipandu oleh para kader setiap seminggu sekali dan pemantauan atau monitoring terkait dengan gula darah sehingga berdampak pada menurunkan angka kejadian 
penyakit hipertensi di wilayah kerja Puskesmas KelurahanPondok Ranggon I Jakarta Timur.

\section{Daftar Pustaka}

A, S., Mulyadi and J, R. (2016). 'Pengaruh senam Diabetes Militus terhadap Kadar Gula Darah Penderita Diabetes Militus Tipe 2 Di Sanggar Senam Persadia Kabupaten Gorontalo', Ejurnal Keperawatan, 4(1).

Ernawati. (2017). Pentalaksanaan Diabetes Mellitus. Buku Ajar Ilmu Gizi Obesitas, Diabetes Mellitus dan Displidemia. Jakarta: EGC.

Hermawan and Rosid. (2017). 'Pengaruh senam Hipertensi Lansia terhadap Penurunan Tekanan Darah Lansia dengan Hipertensi Di Panti Wreda Darma Bhakti Kelurahan Pajang Surakarta', Jurnal Kesehatan, 10(1).

International Diabetes Federation. (2015). 'Diabetes Atlas, sixth edition', ISBN: 2-93(Online version of Diabetes Atlas).

International Diabetes Federation. (2017). 'IDF Diabetes Atlas Eight Edition', in. International Diabetes Federation.

Inzucchi, E. (2003). The Diabetes Melitus Manual. Singapura.

Santoso, M. (2008). Senam Diabetes Indonesia Seri 4 Persatuan Diabetes Indonesia. Jakarta: Yayasan Diabetes Indonesia.

Soemantri, S. and Sarimawar, D. (2002). Trend Pola Penyakit Penyebab Kematian Di Indonesia, Survei Kesehatan Rumah Tangga 1992, 1995, 2001. Indonesia.

Szmuilowicz, E. D., Josefson, J. L. and Metzger, B. E. (2019). 'Gestational Diabetes Mellitus', Endocrinology and Metabolism Clinics of North America, 48(3), pp. 479-493. doi: 10.1016/j.ecl.2019.05.001. 